\title{
NOTES
}

\section{Proposal To Restrict the Genus Bacteroides (Castellani and Chalmers) to Bacteroides fragilis and Closely Related Species}

\author{
H. N. SHAH ${ }^{1 *}$ AND M. D. COLLINS ${ }^{2}$ \\ Department of Oral Microbiology, London Hospital Medical College, London El 2AD, ${ }^{1}$ and AFRC Institute of Food \\ Research, Reading Laboratory, Shinfield, Reading RG2 $9 A T,{ }^{2}$ United Kingdom
}

\begin{abstract}
The genus Bacteroides (Castellani and Chalmers) as presently constituted is phenotypically and phylogenetically extremely heterogeneous. However, biochemical, chemical, and molecular biological data indicate that Bacteroides fragilis (the type species) and related species form a coherent taxonomic group. Therefore, we formally propose that the genus Bacteroides be restricted to the $B$. fragilis group of species, and the description of the genus is emended accordingly.
\end{abstract}

It is now well recognized that the taxonomy of the genus Bacteroides is unsatisfactory and that the genus is in need of revision (see reference 5 for a review). As defined in Bergey's Manual of Systematic Bacteriology (8), the genus comprises a heterogeneous collection of obligately anaerobic, gram-negative, nonsporing, rod-shaped bacteria. More than 50 species are currently recognized on the Approved Lists of Bacterial Names (15). These species exhibit a variety of cellular morphologies and are biochemically and physiologically extremely heterogeneous $(2,16,19,26)$.

The application of biochemical, chemical, and, more recently, molecular biological techniques has done much to clarify the inter- and intrageneric structure of Bacteroides. On the basis of biochemical and chemical criteria there is now good evidence that the genus should be restricted to the type species, Bacteroides fragilis, and closely related organisms (5). These closely related organisms include Bacteroides caccae, Bacteroides distasonis, Bacteroides eggerthii, Bacteroides merdae, Bacteroides ovatus, Bacteroides stercoris, Bacteroides thetaiotaomicron, Bacteroides uniformis, and Bacteroides vulgatus. The organisms of the " $B$. fragilis group" have a relatively narrow guanine-plus-cytosine range (ca. 40 to $48 \mathrm{~mol} \%$ ) and are biochemically homogeneous $(8,10,22)$. B. fragilis and related species are saccharolytic and produce acetic and succinic acids as major metabolic end products of glucose metabolism (8). They differ significantly from other Bacteroides species in possessing enzymes of the hexose monophosphate shunt-pentose phosphate pathway $(5,22) . B$. fragilis and related species also possess sphingolipids, predominantly methyl branched long-chain fatty acids, and menaquinones as the sole respiratory quinones $(5,22)$. On the basis of these criteria several species have now been excluded from the genus and have been given separate generic status. Examples include Anaerorhabdus for Bacteroides furcosus (23); Megamonas for Bacteroides hypermegas (20); Mitsuokella for Bacteroides multiacidus (21); Porphyromonas for Bacteroides asaccharolyticus, Bacteroides endodontalis, and Bacteroides gingivalis (24); Rikenella for Bacteroides microfusus (6); Sebaldella for Bacteroides termiditis (3); and Tissierella for Bacteroides praeacutus (4). Ribosomal ribo-

\footnotetext{
* Corresponding author.
}

nucleic acid studies have also revealed considerable heterogeneity within the genus Bacteroides $(11,17,18,25)$. For example, $16 \mathrm{~S}$ ribosomal ribonucleic acid cataloging studies have led to the reclassification of Bacteroides amylophilus in a new genus, Ruminobacter (25). Ribosomal ribonucleic acid-deoxyribonucleic acid homology studies (11) have also demonstrated that $B$. fragilis and related species form a phylogenetically coherent group distinct from other Bacteroides species, consistent with chemotaxonomic evidence $(5,22)$.

We have suggested on several occasions that the genus Bacteroides should be confined to the $B$. fragilis group of species $(3-5,24)$. However, despite the overwhelming phenotypic and phylogenetic evidence, workers have described a number of new species which bear little resemblance to $B$. fragilis and related species (e.g., Bacteroides forsythus [26] and Bacteroides galacturonicus and Bacteroides pectinophilus [9]). Thus, there is an urgent need to tighten the circumscription of the genus Bacteroides to prevent its continuing use as a repository for a varied collection of obligately anaerobic, gram-negative, nonsporing, rodshaped bacteria. Therefore, we formally propose that the genus Bacteroides be restricted to $B$. fragilis and closely related species and emend the description of the genus accordingly.

Emended description of the genus Bacteroides (Castellani and Chalmers). Gram-negative, obligately anaerobic, nonsporeforming, nonmotile, rod-shaped cells. Cells are approximately 0.5 to 1.3 by 1.6 to $11 \mu \mathrm{m}$. Chemoorganotrophic. Saccharoclastic. Major end products of glucose metabolism are acetic and succinic acids; lower levels of other acids may be produced. Weakly proteolytic. Grows but not always stimulated in the presence of $20 \%$ bile. Esculin is hydrolyzed. Nitrate is not reduced to nitrite. Indole variable. Malate dehydrogenase, glutamate dehydrogenase, glucose6-phosphate dehydrogenase, and 6-phosphogluconate dehydrogenase are present. Cell wall peptidoglycan contains meso-diaminopimelic acid as the diamino acid. The principal respiratory quinones are menaquinones with 10 isoprene units or 11 isoprene units or both. Sphingolipids are produced. Both nonhydroxylated and 3-hydroxylated longchain fatty acids are present. The nonhydroxylated acids are predominantly of the straight-chain saturated, anteiso- and iso-methyl branched-chain types. The deoxyribonucleic acid 
TABLE 1. Outline of the current taxonomic positions of Bacteroides species and related taxa

\begin{tabular}{|c|c|c|}
\hline Species & Taxonomic status and/or comment & Reference(s) \\
\hline \multicolumn{3}{|l|}{ Species currently designated Bacteroides } \\
\hline $\begin{array}{l}\text { B. caccae, B. distasonis, B. eggerthii, B. fragilis, } \\
\text { B. merdae, B. ovatus, B. stercoris, } B . \\
\text { thetaiotaomicron, } B \text {. uniformis, } B \text {. vulgatus }\end{array}$ & \multicolumn{2}{|l|}{ Bacteroides (emended definition) } \\
\hline $\begin{array}{l}\text { B. bivius, B. buccae, B. buccalis, B. corporis, } \\
\text { B. denticola, B. disiens, B. intermedius, } \\
\text { B. heparinolyticus, B. loescheii, B. } \\
\text { melaninogenicus, B. oralis, B. oris, B. oulorum, } \\
\text { B. ruminicola, B. veroralis, B. zoogleoformans }\end{array}$ & $\begin{array}{l}\text { B. melaninogenicus- } B \text {. oralis group; worthy of } \\
\text { separate generic status }\end{array}$ & $5,15,22$ \\
\hline B. levii, B. macacae, B. salivosus & Not Bacteroides; possibly related to Porphyromonas & $5,13,22$ \\
\hline B. ureolyticus, $B$. gracilis & $\begin{array}{l}\text { Not Bacteroides; possibly related to Campylobacter } \\
\text { or Wolinella }\end{array}$ & 17 \\
\hline B. capillosus & Not Bacteroides; generic position uncertain & 5,22 \\
\hline B. cellulosolvens & Not Bacteroides; generic position uncertain & 16 \\
\hline B. coagulans & Not Bacteroides; generic position uncertain & 5,22 \\
\hline B. forsythus & Not Bacteroides; generic position uncertain & 26 \\
\hline B. galacturonicus & Not Bacteroides; generic position uncertain & 9 \\
\hline B. helcogenes & Not Bacteroides; generic position uncertain & 1 \\
\hline B. nodosus & Not Bacteroides; generic position uncertain & 5,22 \\
\hline B. pectinophilus & Not Bacteroides; generic position uncertain & 9 \\
\hline B. pneumosintes & Not Bacteroides; generic position uncertain & 5,22 \\
\hline B. polypragmatus & Not Bacteroides; generic position uncertain & 15 \\
\hline B. putredinis & Not Bacteroides; generic position uncertain & $5,7,22$ \\
\hline B. pyogenes & Not Bacteroides; generic position uncertain & 1 \\
\hline B. splanchnicus & Not Bacteroides; generic position uncertain & 7,22 \\
\hline B. suis & Not Bacteroides; generic position uncertain & 1 \\
\hline B. tectum & Not Bacteroides; generic position uncertain & 12 \\
\hline B. xylanolyticus & Not Bacteroides; generic position uncertain & 19 \\
\hline \multicolumn{3}{|l|}{ New genera for reclassified species } \\
\hline Anaerorhabdus & Formerly $B$. furcosus & 23 \\
\hline Fibrobacter & Formerly $B$. succinogenes & 14 \\
\hline Megamonas & Formerly $B$. hypermegas & 20 \\
\hline Mitsuokella & Formerly $B$. multiacidus & 21 \\
\hline Porphyromonas & $\begin{array}{l}\text { Formerly } B \text {. asaccharolyticus, } B \text {. endodontalis, and } \\
\quad B . \text { gingivalis }\end{array}$ & $5,22,24$ \\
\hline Rikenella & Formerly $B$. microfusus & 6 \\
\hline Ruminobacter & Formerly B. amylophilus & 25 \\
\hline Sebaldella & Formerly $B$. termiditis & 3 \\
\hline Tissierella & Formerly $B$. praeacutus & 4 \\
\hline
\end{tabular}

base composition ranges between 39 and 48 mol\% guanine plus cytosine.

The type species is $B$. fragilis. Other currently described species which conform to the emended description include B. caccae, B. distasonis, B. eggerthii, B. merdae, B. ovatus, $B$. stercoris, $B$. thetaiotaomicron, $B$. uniformis, and $B$. vulgatus. Bacteroides splanchnicus shares a number of characteristics with $B$. fragilis and related species and is often regarded as a member of this group. However, $B$. splanchnicus differs from $B$. fragilis and related species in a number of important biochemical and chemical characteristics and should not be considered a member of the redefined genus (5). Ribosomal ribonucleic acid-deoxyribonucleic acid homology studies also have demonstrated that $B$. splanchnicus is phylogenetically distinct from $B$. fragilis and related species (11). Other validly described Bacteroides species which do not conform to the emended generic description and require further study and reclassification are listed in Table 1.

\section{LITERATURE CITED}

1. Benno, Y., J. Watabe, and T. Mitsuoka. 1983. Bacteroides pyogenes sp. nov., Bacteroides suis sp. nov., and Bacteroides helcogenes sp. nov., new species from abscesses and feces of pigs. Syst. Appl. Microbiol. 4:396-407.

2. Cato, E. P., R. W. Kelley, W. E. C. Moore, and L. V. Holdeman. 1982. Bacteroides zoogleoformans (Weinberg, Nativelle, and Prévot 1983) corrig., comb. nov.: emended description. Int. J. Syst. Bacteriol. 32:271-274.

3. Collins, M. D., and H. N. Shah. 1986. Reclassification of Bacteroides termiditis Sebald (Holdeman and Moore) in a new genus Sebaldella, as Sebaldella termiditis comb. nov. Int. J. Syst. Bacteriol. 36:349-350.

4. Collins, M. D., and H. N. Shah. 1986. Reclassification of Bacteroides praeacutus Tissier (Holdeman and Moore) in a new genus, Tissierella, as Tissierella praeacuta comb. nov. Int. J. Syst. Bacteriol. 36:461-463.

5. Collins, M. D., and H. N. Shah. 1987. Recent advances in the taxonomy of the genus Bacteroides, p. 249-258. In S. P. Borriello, J. M. Hardie, B. S. Drasar, B. I. Duerden, M. J. Hudson, and R. J. Lyson (ed.), Recent advances in anaerobic bacteriology. Martinus Nijhoff Publishers, Dordrecht, The Netherlands.

6. Collins, M. D., H. N. Shah, and T. Mitsuoka. 1985. Reclassification of Bacteroides microfusus (Kaneuchi and Mitsuoka) in a new genus Rikenella, as Rikenella microfusus comb. nov. Syst. Appl. Microbiol. 6:79-81.

7. Hammann, R., and H. Werner. 1983. Guanine-plus-cytosine content and production of phenylacetic acid by Bacteroides 
putredinis (Weinberg et al., 1937) Kelly (1957) and Bacteroides splanchnicus (Werner et al. 1975). Int. J. Syst. Bacteriol. 33: 120-121.

8. Holdeman, L. V., R. W. Kelley, and W. E. C. Moore. 1984. Genus I. Bacteroides Castellani and Chalmers 1919, 959 ${ }^{\mathrm{AL}}$, p. 604-631. In N. R. Krieg and J. G. Holt (ed.), Bergey's manual of systematic bacteriology, vol. 1. The Williams \& Wilkins Co., Baltimore.

9. Jensen, N. S., and E. Canale-Parola. 1986. Bacteroides pectinophilus sp. nov. and Bacteroides galacturonicus sp. nov.: two new pectinolytic bacteria from the human intestinal tract. Appl. Environ. Microbiol. 52:880-887.

10. Johnson, J. L. 1978. Taxonomy of the Bacteroides. I. Deoxyribonucleic acid homologies among Bacteroides fragilis and other saccharolytic Bacteroides species. Int. J. Syst. Bacteriol. 28: 245-256.

11. Johnson, J. L., and B. Harich. 1986. Ribosomal ribonucleic acid homology among species of the genus Bacteroides. Int. J. Syst. Bacteriol. 36:71-79.

12. Love, D. N., J. L. Johnson, R. F. Jones, M. Bailey, and A. Calverley. 1986. Bacteroides tectum sp. nov., characteristics of other nonpigmented Bacteroides isolates from soft-tissue infections from cats and dogs. Int. J. Syst. Bacteriol. 36:123-128.

13. Love, D. N., J. L. Johnson, R. F. Jones, and A. Calverley. 1987. Bacteroides salivosus sp. nov., an asaccharolytic, black-pigmented species from cats. Int. J. Syst. Bacteriol. 37:307-309.

14. Montgomery, L., B. Flesher, and D. Stahl. 1988. Transfer of Bacteroides succinogenes (Hungate) to Fibrobacter gen. nov. as Fibrobacter succinogenes comb. nov. and description of Fibrobacter intestinalis sp. nov. Int. J. Syst. Bacteriol. 38:430435 .

15. Moore, W. E. C., E. P. Cato, and L. V. H. Moore. 1985. Index of the bacterial and yeast nomenclatural changes published in the International Journal of Systematic Bacteriology since the 1980 Approved Lists of Bacterial Names (1 January 1980 to January 1985). Int. J. Syst. Bacteriol. 35:382-407.

16. Murray, W. D., L. C. Sowden, and J. R. Colvin. 1984. Bacteroides cellulosolvens sp. nov., a cellulolytic species from sewage sludge. Int. J. Syst. Bacteriol. 34:185-187.

17. Paster, B. J., and F. E. Dewhirst. 1988. Phylogeny of campylo- bacters, wolinellas, Bacteroides gracilis, and Bacteroides ureolyticus by $16 \mathrm{~S}$ ribosomal ribonucleic acid sequencing. Int. J. Syst. Bacteriol. 38:62-65.

18. Paster, B. J., W. Ludwig, W. G. Weisburg, E. Stackebrandt, R. B. Hespell, C. M. Hahn, H. Reichenbach, K. O. Stetter, and C. R. Woese. 1985. A phylogenetic grouping of the Bacteroides, cytophagas and certain flavobacteria. Syst. Appl. Microbiol. 6: $34-42$.

19. Scholten-Koerselman, I., F. Houwaard, P. Janssen, and A. J. B. Zehnder. 1986. Bacteroides xylanolyticus sp. nov., a xylanolytic bacterium from methane producing cattle manure. Antonie van Leeuwenhoek J. Microbiol. Serol. 52:543-554.

20. Shah, H. N., and M. D. Collins. 1982. Reclassification of Bacteroides hypermegas (Harrison and Hansen) in a new genus Megamonas, as Megamonas hypermegas comb. nov. Zentralbl. Bakteriol. Parasitenkd. Infektionskr. Hyg. Abt. 1 Orig. Reihe C 3:394-398.

21. Shah, H. N., and M. D. Collins. 1982. Reclassification of Bacteroides multiacidus (Mitsuoka, Terada, Watanabe and Uchida) in a new genus Mitsuokella, as Mitsuokella multiacidus comb. nov. Zentralbl. Bakteriol. Parasitenkd. Infektionskr. Hyg. Abt. 1 Orig. Reihe C 3:491-494.

22. Shah, H. N., and M. D. Collins. 1983. Genus Bacteroides: a chemotaxonomical perspective. J. Appl. Bacteriol. 55:403-416.

23. Shah, H. N., and M. D. Collins. 1986. Reclassification of Bacteroides furcosus Veiollon and Zuber (Hauduroy, Ehringer, Urbain, Guillot and Magron) in a new genus Anaerorhabdus, as Anaerorhabdus furcosus comb. nov. Syst. Appl. Bacteriol. 8: 86-88.

24. Shah, H. N., and M. D. Collíns. 1988. Proposal for reclassification of Bacteroides asaccharolyticus, Bacteroides gingivalis, and Bacteroides endodontalis in a new genus, Porphyromonas. Int. J. Syst. Bacteriol. 38:128-131.

25. Stackebrandt, E., and H. Hippe. 1986. Transfer of Bacteroides amylophilus to a new genus Ruminobacter gen. nov., nom. rev. as Ruminobacter amylophilus comb. nov. Syst. Appl. Microbiol. 8:204-207.

26. Tanner, A. C. R., M. A. Listgarten, J. L. Ebersole, and M. N. Strzempko. 1986. Bacteroides forsythus sp. nov., a slowgrowing, fusiform Bacteroides sp. from the human oral cavity. Int. J. Syst. Bacteriol. 36:213-221. 